\title{
PENGINGKARAN HAK MASYARAKAT ADAT ATAS TANAH ULAYAT OLEH KEBIJAKAN KEHUTANAN
}

\author{
Oleh: Setiati Widihastuti \\ (Jurusan PKn dan Hukum FISE UNY)
}

\begin{abstract}
Forest is the part of customary system of the tribe society. However, the forest management done by them is not facilitated in the forestry policy. The centralistic forestry policy causes the overlapping conception of the tribe forest to the state forest. While it formal normative aspect causes the acces of the tribes to the forest closed and causes reduction of wisdom-based supervision conducted by them. In fact, the community wisdom-based supervision in the socio-culture potential needing a revitalization and development as the new basis of the change of natural resources management policy which is recently controlled by the goverment proved to be the cause of law and economy harassment to the tribes society of Indonesia. Now we need to change the perception about the forest natural recource management policy controlled only by the government of the forestry instances. It should be the policy based on the community and its development principles to realize the regulation of the forest natural resources consumption. Therefore, the area division is needed to overcome the problems.
\end{abstract}

Key Words: forestry policy, customary right, tribes society

\section{Pendahuluan}

Sebagai negara kepulauan yang memiliki 17.000-an pulau, Indonesia dikenal sebagai negara megabio and cultural diversity yang memiliki 47 ekosistem utama dan lebih dari 250 kelompok etnis dengan lebih dari 500 bahasa yang berbeda. Keberadaan keanekaragaman hayati dan budaya tersebut bertumpu pada keberadaan masyarakat adat yang hidup dan tersebar di seluruh pelosok nusantara. AMAN (Asosiasi Masyarakat Adat Nusantara) memperkirakan bahwa dari sekitar 240 juta penduduk Indonesia, antara 50 sampai 70 juta di antaranya adalah masyarakat adat, yaitu penduduk yang hidup dalam satuan-satuan komunitas berdasarkan asal-usul leluhur secara turun temurun di atas suatu wilayah adat, yang memiliki kedaulatan atas tanah dan kekayaan alam, kehidupan sosial budaya yang diatur oleh hukum adat, dan lembaga adat yang mengelola keberlangsungan kehidupan masyarakatnya (Abdon Nababan, 2002). Dari jumlah tersebut, diperkirakan 30 juta sampai dengan 50 juta di antaranya adalah masyarakat adat yang kehidupannya masih tergantung pada hutan adat, yaitu ekosistem hutan yang berada di wilayah adatnya.

Fakta mengenai ketergantungan masyarakat adat pada hutan sebagai sumber kehidupan dan mata pencahariannya tersebut perlu disikapi oleh pemerintah secara arif. Semula ditetapkannya Undang-Undang No. 5 Tahun 1960 tentang Peraturan 
Dasar Pokok-Pokok Agraria atau UUPA, sempat menimbulkan harapan bahwa undang-undang yang bersifat populis tersebut dapat memberikan perlindungan kepada berbagai pranata hukum adat yang tidak bertentangan dengan kepentingan nasional dan negara. Harapan itu antara lain berupa perlindungan dan pengakuan terhadap eksistensi masyarakat adat dengan hak ulayatnya dan perlindungan terhadap hutan adat yang merupakan jantung kehidupan masyarakat tersebut. Namun, kenyataannya selama rezim Orde Lama yang dilanjutkan dengan rezim Orde Baru berkuasa, keberpihakan bukan kepada rakyat (masyarakat adat), melainkan kepada kaum bermodal. Simak saja misalnya, pengingkaran penguasa terhadap hak masyarakat adat atas hutan (hak ulayat) dengan diberlakukannya UU No. 5 Tahun 1967 tentang Ketentuan-ketentuan Pokok Kehutanan (UUPK), yang ditandai dengan diputusnya hak ulayat atas hutan melalui penunjukan fungsi kawasan hutan yang diiringi dengan penguatan hutan negara di kawasan hutan. UUPK hanya mengakui hutan rakyat sebagai hutan yang berada di atas hak milik, sedangkan hutan adat (hutan di atas hak ulayat) tidak dikenal lagi. Dengan ditetapkannya UUPK, pemerintah telah menetapkan kawasan hutan negara secara sepihak seluas 143

\section{ribu hektar, atau kurang dari lebih $70 \%$ dari seluruh luas daratan negara}

Indonesia. Penetapan ini dilakukan secara sepihak dan tidak didasari atas pengakuan atas keberadaan wilayah-wilayah adat yang ada jauh sebelum negara Indonesia didirikan. Dan di atas tanah hutan negara tersebut, ratusan konsesi diberikan, baik untuk eksplorasi hutan, perkebunan ataupun penambangan tanpa mempedulikan bahwa hutan ataupun tambang tersebut terletak di atas tanah wilayah adat. Kasus perseteruan antara suku Amungme dan Komoro dengan PT Freeport McMoran Indonesia merupakan contoh di mana konsesi pertambangan diberikan oleh pemerintah di atas wilayah adat. Komnas HAM (2006: 14)

menyebutkan bahwa kebutuhan sumber daya alam dengan investasi skala besar yang didukung oleh pemilik modal asing dan atau domestik (konglomerasi) memang merupakan modal utama pembangunan pada rezim Orde Baru.

Setelah rezim Orde Baru tumbang, lahirlah Orde Reformasi yang bertekad membawa masyarakat menuju civil society yang ditengarai dengan diundangkannya berbagai peraturan perundangan yang berpihak kepada masyarakat. Simak Pasal 18 
B ayat (2) UUD 1945 yang menyatakan bahwa negara mengakui dan menghormati kesatuan-kesatuan masyarakat hukum adat berikut hak-hak tradisionalnya, simak pula Pasal 6 ayat (2) Undang-Undang No. 39 Tahun 1999 tentang Hak Asasi Manusia yang menyebutkan bahwa identitas budaya masyarakat, termasuk hak atas tanah ulayat dilindungi dan selaras dengan perkembangan jaman. Hal yang sama juga dengan keluarnya Peraturan Menteri Agraria No. 5 Tahun 1999 tentang Pedoman Penyelesaian Masalah Hak Ulayat. Namun, bergulirnya angin segar reformasi ini belum memberikan perlindungan hukum secara utuh pada hak pengelolaan masyarakat adat terhadap sumber daya hutan (hak ulayat). Kebijakan kehutanan kontemporer (UU No. 41 Tahun 1999 tentang Kehutanan atau UUK) yang tidak begitu jauh dengan kebijakan kehutanan di masa Orde Baru (UUPK) menjadi salah satu buktinya. Lemahnya pengakuan dan perlindungan hak adat atas hutan, secara gamblang terlihat pada tumpang tindihnya status hutan adat dengan status hutan negara yang berdampak lebih jauh pada berkurangnya intensitas hubungan masyarakat adat dengan hutannya serta tertutupnya akses masyarakat adat pada kawasan hutan

\section{Makna Tanah, Hutan, dan Alam bagi Masyarakat Adat}

Dari keseluruhan masyarakat adat di seantero Indonesia ini, diperkirakan 30 sampai 50 juta di antaranya adalah masyarakat adat yang kehidupannya masih tergantung pada hutan, yaitu suatu kesatuan ekosistem berupa hamparan lahan berisi sumber daya alam hayati yang didominasi pepohonan dalam persekutuan alam lingkungannya, yang satu dengan yang lain tidak dapat dipisahkan. Hutan merupakan bagian tak terpisahkan dari siklus kehidupan komunitas adat penghuninya yang lazim disebut sebagai masyarakat adat. Sebagian besar masyarakat adat di Indonesia hidup tergantung pada hutan dan mengembangkan sistem pengelolaan sumber daya alam (hutan, laut, sungai) yang unik dan luar biasa yang menunjukkan kualitas pengetahuan mereka dan kedekatan hubungan mereka dengan alam. Pada umumnya masyarat adat penghuni hutan adat itu mempunyai kesadaran bahwa manusia adalah bagian dari alam yang harus saling memelihara dan menjaga keseimbangan serta harmoni di antara kedua komponen ekosistem ini. Untuk menjaga keharmonisan hubungan antara manusia dengan alam (hutan adat), masyarakat adat menyusun suatu pranata sosial mengenai pengelolaan tanah hutan, yang dikenal sebagai hak ulayat.

Melalui pranata sosial (hak ulayat) tersebut, masyarakat adat telah mengembangkan konsep penguasaan/kepemilikan bersama (secara komunal) dan 
bersifat eksklusif atas suatu kawasan hutan adat (Bestari dan Abdon, 2003:2). Untuk mendukung pengelolaan hutan sebagai hak kolektif, masyarakat adat juga memiliki sistem pengetahuan, hukum adat, dan struktur kelembagaan adat yang memberikan kemampuan bagi anggota masyarakat adat untuk memecahkan masalah-masalah yang dihadapi berkaitan dengan pemanfatan sumberdaya hutan. Sebagai contoh, di Maluku dan Papua, masyarakat adat yang tinggal di pulau-pulau kecil maupun di wilayah pesisir memiliki sistem sasi atau larangan memanen atau mengambil dari alam untuk waktu tertentu. Di wilayah Kepulauan Haruku dan Ambon, juga dikenal sasi ikan lompa yang menunjukkan salah satu kearifan tradisional dalam menjaga kelestarian lingkungan. Dengan ditetapkan sasi atas spesies tertentu oleh Kewang (polisi adat di Maluku Tengah), maka ketentuan ini memungkinkan berkembang biaknya ikan lompa, untuk kemudian dipanen ketika sasi dibuka kembali (Tempo, Juni 2004). Dalam praktik pengelolaan hutan oleh masyarakat Nagari di Sumatera Barat, terdapat aturan dan tata kelola hutan adat yang berkesinambungan, misalnya bagi setiap pemuda yang akan menikah diwajibkan menanam meranti sebanyak 50 pohon dan kayu manis 100 batang, atau diberlakukan larangan menebang kayu di hulu sungai dan pinggir tebing curam (Nurul Firmansyah, 2006: 9). Di Kalimantan, masyarakat Dayak memiliki keyakinan bahwa "Tanah adalah Hidup dan Nafas Kami”, dan di Papua Barat, hampir seluruh masyarakat adat meyakini bahwa "Tanah kita, hidup kita" (Tempo, Juni 2004). Sementara itu, di Seruyan Kalimantan Tengah, hak ulayat tampak dalam wujud: a) kaleka uluh helu, yang isinya berupa tempat sandung, kebun buah-buahan; b) petak pali: sebagai tempat terlarang untuk dimasuki secara tidak mematuhi aturan adat; c) petak bahu himba sebagai tempat bekas berladang yang dalam putaran beberapa tahun akan digarap kembali (Marsel

\section{Selamat, 2004: 4). Oleh masyarakat adat, hutan adat disadari}

sebagai jantung kehidupan mereka yang harus dijaga keberlangsungannya. Bagi masyarakat adat, tanah lingkungan alam termasuk hutan adat, adalah sumber kehidupan dan sangat bermakna dalam segala aspek kehidupan. Sebagian dari masyarakat mengibaratkan bumi sebagai "ibu" mereka. Merusak alam sama dengan menyakiti "ibu" mereka, demikian juga mengotori bumi.

Hutan, tanah, air, dan sumber daya lainnya merupakan bagian integral dari wilayah dan hak ulayat yang menjadi simbul pengikat hubungan antar anggota masyarakat adat. Ulayat bukan hanya berfungsi ekonomis, tetapi juga berfungsi 
magis, sosial, dan budaya. Prinsip inilah yang kemudian menjadi landasan dalam mengelola hutan oleh warga masyarakat adat. Pengelolaan hutan adat dengan hak ulayat ini dapat dicermati dengan menyimak contoh pengelolaan hutan di Nagari Guguk Malalo, Sumatra Barat. Pengaturan hubungan antara masyarakat Nagari dengan hutan mempergunakan dua ketentuan, yaitu "pantangan" dan "larangan" yang diterapkan sesuai dengan asas hukum adat, yaitu asas kepatutan dan tingkat kebutuhan masyarakat untuk menciptakan tertib sosial. Terminologi "pantangan" terkait dengan hal-hal yang tidak diperbolehkan dalam nilai-nilai kultural dan religi, sedangkan "larangan" mengacu pada hal-hal yang tidak diperbolehkan, yang berhubungan dengan kepentingan langsung masyarakat, karena dianggap berdampak dan berpengaruh besar. Pemanfaatan hutan oleh masyarakat Nagari diutamakan bagi perluasan lahan pertanian (clearing it for agriculture) dengan mempertimbangkan keberlangsungan dan keseimbangan alam, karena pertanian dan perladangan merupakan mata pencarian utama. Pembukaan lahan dilakukan di ulayat kaum, ulayat suku maupun ulayat nagari. Pemanfatan lain berupa hasil hutan kayu dan non kayu (Nurul Firmansyah, 2006: 6-7)

Keberadaan hutan adat yang dikelola masyarakat adat dengan hak ulayat saat ini semakin mengkawatirkan, seiring dengan semakin meningkatnya kebutuhan negara akan tanah hutan. Penetapan kawasan hutan secara sistemik telah dilakukan pada masa Orde Baru dengan menetapkan kawasan hutan negara seluas 120 juta hektar yang dibagi-bagi atas kawasan konservasi, hutan lindung, hutan produksi terbatas, hutan produksi tetap dan hutan produksi konversi. Lebih merisaukan lagi karena kebutuhan pemerintah akan tanah hutan tersebut diikuti dengan tindakan pengingkaran terhadap hak masyarakat adat atas hutan. Misalnya, UU No. 5 Tahun 1967 dengan sengaja telah menafikan hak ulayat atas hutan melalui penunjukan fungsi kawasan hutan yang diikuti dengan penguatan hutan negara di atas kawasan hutan. UU tersebut juga hanya mengakui hutan rakyat sebagai hutan yang berada di atas hak milik, sementara hutan adat atau hutan di atas hak ulayat dengan sistem penguasaan bersifat komunal tidak dikenal. Kondisi ini tentu saja merisaukan, karena hutan adat yang merupakan sumber kehidupan bagi masyarakat adat semakin tergusur. Sementara itu penggunaan hak pengelolaan atas tanah adat (hak ulayat) serta hak masyarakat adat untuk memanfaatkan hasil hutan dibatasi oleh berbagai persyaratan yang sangat membelenggu. Maka sangatlah wajar kalau isu tentang eksistensi hak ulayat yang merupakan hak masyarakat adat untuk mengelola tanah (hutan) adat yang menjadi otoritasnya perlu mendapat pemikiran yang proporsional. 


\section{Kebijakan Kehutanan Mereduksi Hak Masyarakat Adat dan Hutan Adat}

Hutan sebagai salah satu kekayaan alam yang menjadi modal pembangunan nasional memiliki manfaat bagi kehidupan dan penghidupan masyarakat (masyarakat adat), baik manfaat ekologi, sosial, budaya, maupun ekonomi. Oleh konstitusi diamanatkan agar sumber daya alam (hutan) dipergunakan untuk sebesar-besar kemakmuran rakyat (Pasal 33 ayat (1) UUD 1945). Didorong oleh kesadaran bahwa keberadaan hutan yang luasnya semakin berkurang, maka diperlukan pengelolaan secara arif dan pemeliharaan hutan dengan prinsip berkesinambungan, sehingga diundangkanlah UU No. 41 Tahun 1999 tentang Kehutanan (UUK) menggantikan UU No. 5 Tahun 1967 (UUPK).

Jika dicermati pasal-pasalnya, undang-undang kehutanan yang baru juga tidak lebih baik dari undang-undang pendahulunya. Demikian juga halnya jika undang-undang tersebut dikaji dari sudut pandang sistem pengelolaan hutan. Secara teoritis terdapat dua paradigma dalam sistem pengelolaan hutan, yakni: a) pengelolaan sumber daya alam (hutan) yang berpusat pada negara (state-based forest management), yang menempatkan pemerintah dalam posisi sentral dan menentukan sedangkan masyarakat hanya berperan sebagai pelengkap, dan b) pengelolaan sumber daya alam oleh masyarakat (community-based forest management), yang menempatkan masyarakat sebagai pelaku utama dan pemerintah berperan sebagi fasilitator dan administrator untuk mendukung proses tersebut. Jika dicermati beberapa pasal dalam UUK No. 41 Tahun 1999, dapat ditengarai bahwa visi UUK belum menegaskan keberpihakan pada kepentingan dan perlindungan hak-hak masyarakat, terutama masyarakat adat. Hal ini tampak dalam dominasi kekuasaan negara yang tercermin dalam kewenangan pengelolaan kehutanan yang sentralistik, dan tidak memberi hak kepada masyarakat untuk berperan serta dalam proses pengelolaan sumber daya hutan, serta tidak mengakui keberadaan hutan yang dipunyai oleh masyarakat adat. Akibatnya, dalam konteks pertanahan, kehutanan, dan pertambangan, hak-hak masyarakat adat dilanggar secara sistematik. Misalnya, pelanggaran hak atas kepemilikan terjadi ketika hak-hak masyarakat adat atas wilayahnya tidak diakui dan dinyatakan secara sepihak oleh pemerintah sebagai kawasan hutan negara ataupun wilayah kuasa pertambangan. Hak atas makanan dan gizi yang mencukupi dilanggar ketika hutan, kebun, dan ladang di wilayah adat yang merupakan sumber makanan mereka diganti dengan "hutan" monokultur yang sangat miskin sumber pangan oleh kegiatan HPH (Hak Pengelolaan Hutan) maupun 
perkebunan besar yang "diijinkan" oleh negara. Pelanggaran hak terjadi, ketika negara memberi ijin kepada perusahaan perikanan untuk mengeksplorasi hasil laut tanpa memperhatikan sasi (larangan memanen ikan) yang selama ini berlakukan sebagai pranata sosial yang bersumber pada kearifan lokal (Tempo, 2004).

Peran negara yang sentralistik juga dimunculkan dalam wujud pemerintah yang tidak memberi tempat yang wajar bagi masyarakat untuk bersama-sama dengan pemerintah membuat perencanaan dan melakukan pengawasan terhadap pemanfaatan sumber daya hutan. Monopoli kewenangan ini mudah mengaburkan peran negara untuk "menguasai" hutan, seperti yang diamanatkan Pasal 33 ayat (3) UUD 1945, menjadi "memiliki" dengan segala dampaknya (Maria, 2002: 192).

Tidak bisa disangkal bahwa "semangat monopoli" tersebut nyaris menghancurkan hutan adat dan kearifan lokal dalam pengelolaan sumber daya alam melalui kebijakan penebangan hutan komersial dengan sistem konsesi HPH. Sampai dengan Juli 2004, DEPHUTBUN mencatat lebih dari 652 HPH dengan luas keseluruhan areal konsesi 69,4 juta hektar. Sebagian besar dari kawasan hutan yang dikonsesikan oleh pemerintah kepada perusahaan swasta dan BUMN tersebut berada dalam wilayah-wilayah adat. Dari 320 HPH aktif yang luas areal konsesi keseluruhannya 41,2 juta hektar diidentifikasi bahwa 28\% (11,7 juta hektar) hutannya sudah rusak atau menjadi lahan kosong dan tanah pertanian (Bestari dan Abdon, 2003: 4). Dapat dipastikan bahwa di kawasan hutan ber-HPH telah terjadi penebangan kayu secara besar-besaran, dengan menggunakan fasilitas "logging road" dan "skidding road", perkebunan skala besar, perladangan berpindah dan sebagainya, yang dampaknya adalah porak porandanya hutan adat yang selama ratusan tahun menjadi jantung kehidupan masyarakat adat.

Cara pandang UUPK No. 5 tahun 1967 yang tidak mengakui hak-hak masyarakat adat, juga mewarnai UUK (UU No. 41 Tahun 1999). Jika UUPK membedakan status hutan sebagai hutan negara dan hutan milik, maka UUK membedakan status hutan sebagai: a) hutan negara, yakni hutan yang berada pada tanah yang tidak dibebani hak atas tanah, dan b) hutan hak, yakni hutan yang berada pada tanah yang dibebani hak atas tanah (Pasal 5 UUK ayat 1). Kalaupun UUK mengakomodasi keberadaan hutan adat, tetapi tidak lebih dari "hanya" memasukkan hutan adat dalam ruang lingkup hutan negara. Dengan kata lain, hutan adat tidaklah lebih sebagai bagian dari hutan negara, seperti ditegaskan dalam ketentuan umum UUK yang menyebutkan hutan adat adalah hutan negara yang berada dalam wilayah masyarakat hukum adat. Dan faktanya ambiguitas pengakuan terhadap hutan adat 
tersebut tidak memberi pijakan hukum yang berarti bagi keberadaan hutan adat. Sebagai konsekuensinya adalah tidak diakuinya keberadaan hutan adat di samping hutan negara dan hutan milik, yang berakibat bukan saja berkurangnya intensitas hubungan masyarakat adat terhadap hutannya, tetapi juga "hilangnya" hutan masyarakat adat. Sebagai contoh dapat disimak masalah yang menimpa warga desa Mandigangin, penduduk asli Melayu dan Sakai yang dulu memiliki lahan hutan yang sangat luas dan secara konstitusional dilindungi oleh adat. Lahan tersebut kemudian diambil alih oleh perusahaan pulp PT Arara Abadi dan difungsikan sebagai perkebunan tanpa melalui proses negosiasi dan dilakukan di bawah ancaman aparat negara. Legalitas pengambilalihan dan pengelolaan hutan tersebut patut dipertanyakan, meskipun pihak PT Arara Abadi telah mengantongi ijin HPH dari pemerintah. Hal ini disebabkan karena ijin HPH tersebut dikeluarkan berdasarkan pada interpretasi yang cacat terhadap "lahan tidak berpemilik" yang secara tidak legal telah menetapkan hutan milik masyarakat adat sebagai "hutan negara" (Bestari dan Abdon, 2003)

Tidak tegasnya pengakuan tentang keberadaan hutan adat oleh UUK itu juga menimbulkan kejanggalan dengan diaturnya keberadaan masyarakat adat dalam Pasal 67 UUK. Pada Pasal 67 UUK ayat (1) disebutkan bahwa "masyarakat hukum adat sepanjang menurut kenyataannya masih ada dan diakui keberadaannya, berhak untuk: a) melakukan pemungutan hasil hutan untuk pemenuhan kehidupan seharihari masyarakat adat yang bersangkutan; b) melakukan kegiatan pengelolaan hutan berdasarkan hukum adat yang berlaku dan tidak bertentangan dengan undangundang, dan c) mendapatkan pemberdayaan dalam rangka meningkatkan kesejahteraannya". Pengukuhan keberadaan dan hapusnya masyarakat hukum adat sebagaimana dimaksud pada ayat (1) ditetapkan dengan Peraturan Daerah. Ketentuan lebih lanjut sebagaimana dimaksud pada ayat (1) dan ayat (2) di atas dengan Peraturan Daerah.

Pengakuan yang mendua ini memang sudah pasti menimbulkan ketidakpastian terhadap hak masyarakat adat dalam pengelolaan hutan. Pengakuan yang mendua ini juga tampak dalam bentuk persyaratan-persyaratan yang sulit dipenuhi oleh masyarakat hukum adat. Secara berturut pengakuan bersyarat itu dapat dilihat pada beberapa pasal UUD 1945, yakni: a) Pasal 18 B ayat (2) UUD 1945 dalam penggalan kalimat "... sepanjang masih hidup", dan b) Pasal 28I ayat (3) dalam penggalan kalimat "...... selaras dengan perkembangan jaman dan peradaban" dan dalam penggalan lain "........ selaras dengan prinsip negara kesatuan Republik 
Indonesia". Persyaratan di atas memberikan peluang munculnya tafsiran yang beraneka ragam dan sangat mudah diselewengkan sesuai dengan kepentingan pemangku kepentingan dan kebijakan.

Peraturan bersyarat tersebut juga terdapat dalam Pasal 67 ayat (1) huruf d yang menyebutkan sebagai syarat keberadaan masyarakat adat adalah "ada pranata dan perangkat hukum khususnya peradilan adat yang masih ditaati”. Ketentuan tersebut membuat masyarakat adat tidak mempunyai dasar yang kuat untuk memperjuangkan haknya dalam pengelolaan hutan. Peradilan adat yang disebutkan dalam persyaratan di atas bertentangan dengan Pasal 2 ayat (3) Undang-Undang No. 48 Tahun 2009 tentang Ketentuan Pokok Kekuasaan Kehakiman yang menyebutkan bahwa "semua peradilan di seluruh wilayah RI adalah Peradilan Negara yang diatur dengan undang-undang”. Dengan kata lain, pasal tersebut mengatur penghapusan pangadilan adat. Ketentuan undang-undang tersebut dapat ditafsirkan sebagai ketidaksungguhan pemerintah untuk mengakui dan melindungi hak masyarakat adat dalam mengelola hutan. Pengakuan dan penghormatan tersebut hanya bersifat deklaratif dan pada tataran operasional masih sangat jauh dari harapan rasa keadilan masyarakat adat.

Karena itu, untuk kekonsistenan konsep dan dengan mempertimbangkan bahwa UUK mengatur eksistensi dan hak masyarakat adat di bidang kehutanan, seharusnya UUK juga harus secara tegas menyebutkan secara eksplisit tentang hutan adat, di samping hutan negara dan hutan hak. Hal ini karena hubungan masyarakat adat dan hutan adat adalah bagaikan sekeping mata uang, dalam arti apabila di satu sisi terdapat masyarakat adat, di sisi lainnya pasti terdapat hutan adat yang dikelola oleh masyarakat adat tersebut dengan mempergunakan hak ulayat.

\section{Tertutupnya Akses Masyarakat Adat dalam Pengelolaan Hutan}

Proses penetapan kawasan hutan yang sentralistik dan tidak partisipatif seperti paparan di atas, berdampak pada hilang dan tertutupnya akses masyarakat adat terhadap hutan, atau setidaknya telah mengaburkan hak ulayat masyarakat adat terhadap hutannya. Padahal UUK telah mengatur hak-hak masyarakat (termasuk masyarakat adat) dalam Pasal 68, sebagai berikut:

a. Masyarakat berhak menikmati kualitas lingkungan hidup yang dihasilkan hutan.

Pengertian menikmati kualitas lingkungan ini termasuk untuk memperoleh manfaat sosial dan budaya bagi masyarakat yang tinggal di dalam dan sekitar hutan. 
b. Masyarakat berhak untuk:

1) memanfaaatkan hutan dan hasil hutan sesuai dengan peraturan perundangundangan yang berlaku,

2) mengetahui rencana peruntukan hutan, pemanfaatan hasil huta, dan informasi kehutanan,

3) memberi informasi, saran serta pertimbangan dalam pembangunan kehutanan,

4) melakukan pengawasan terhadap pelaksanaan pembangunan kehutanan.

c. Masyarakat di dalam dan di sekitar hutan berhak memperoleh kompensasi karena hilangnya akses akan hutan sekitarnya sebagai lapangan kerja untuk memenuhi kebutuhan hidupnya akibat penetapan kawasan hutan, sesuai peraturan perundangan yang berlaku.

Meskipun apa yang menjadi hak masyarakat sudah diatur dalam UUK, tetapi ambiguitas pengakuan terhadap hutan adat berakibat pada kaburnya status hutan adat atas hutan negara, yang selanjutnya berdampak pada hilangnya akses masyarakat terhadap hutan dan tidak gampangnya merealisasikan hak masyarakat atas pemanfaatan hutannya. Sebagai contoh adalah larangan pemanfaatan kayu oleh masyarakat adat untuk kebutuhan Nagari di daerah Kabupaten Tanah Datar. Atau penggusuran masyarakat adat dari hutan adat yang merupakan sumber kehidupannya, eksploitasi sektor pertambangan pada sumber-sumber alam di wilayah adat. Contoh yang sangat fenomenal adalah orang Dayak di Kalimantan yang mengalami begitu banyak dampak eksploitasi sektor kehutanan dan pertambangan. Ketergantungan masyarakat adat pada hutan cukup besar, sehingga pembatasan atau penutupan akses mereka dalam pengelolaan hutan berdampak langsung bagi ekonomi masyarakat. Lebih jauh kondisi tersebut juga berdampak terhadap pola-pola pengelolaan hutan berdasarkan nilai-nilai adat, dan bahkan hilangnya hak ulayat masyarakat terhadap hutan mereka.

Tertutupnya akses masyarakat adat pada hutan juga ditandai dengan kebijakan pemerintah yang berisi pembatasan pemungutan hasil hutan non kayu, misalnya dengan diberlakukannya Peraturan Daerah Kabupaten Tanah Datar tentang Izin Pengambilan Hasil Hutan Ikutan. Perda tersebut memberikan pembatasan terhadap masyarakat dalam pemanfaatan hasil hutan non kayu. Bentuk peraturan yang bersifat membatasi dan berimbas menutup akses masyarakat adat untuk mengelola hutan non kayu, antara lain: (1) tidak dikenalnya institusi adat sebagai subjek pemanfaatan hasil hutan; (2) sistem perizinan pemanfaatan yang sangat 
prosedural dan bertumpu pada kebijaksanaan bupati kepala daerah sebagai satusatunya subjek pengelola hutan; dan (3) tidak dikenalnya lagi hutan ulayat atau hutan adat (Nurul Firmansyah, 2006: 17).

Pengelolaan sumber daya hutan berbasis masyarakat, termasuk masyarakat adat, seharusnya dijadikan paradigma acuan dalam menerjemahkan penghormatan hak-hak masyarakat adat dan pelestarian lingkungan, karena pembatasan-pembatasan seperti di atas dapat berefek domino terhadap kondisi sosial budaya dan ekonomi masyarakat. Rentetan dampak tersebut antara lain dapat berupa melunturnya nilainilai kebersamaan, guyub yang merupakan semangat dasar pengelolaan sumber daya alam oleh masyarakat adat. Melunturnya nilai kebersamaan tersebut dibarengi dengan berkembangnya nilai individualisme yang membuat sebagian masyarakat adat juga ikut bekerja bersama pihak-pihak yang mengembangkan kegiatan yang merusak lingkungan. Sebagai contoh adalah keterlibatan mereka dalam kegiatan pencurian kayu, pencurian hasil hutan pembabatan hutan dan penambangan skala besar baik sebagai karyawan sebuah perusahaan legal dan illegal, maupun sebagai perorangan dan atau kelompok masyarakat yang tidak memiliki alternatif sumber pendapatan lain. Dengan kata lain penerapan kebijakan kehutanan di atas juga dapat berimplikasi pada hilangnya kontrol masyarakat ada terhadap hutan (Nurul Firmansyah, 2006: 17). Fenomena pencurian kayu (illegal logging) yang dilakukan oleh "cukong" kayu dengan melibatkan oknum warga masyarakat adat sebagai operasional kegiatannya, bukanlah karena lemahnya penegakan hukum semata, melainkan menjadi salah satu bukti lunturnya nilai kebersamaan dan berkembangnya nilai individualisme serta hilangnya pengawasan masyarakat terhadap hutan.

Kondisi tersebut dikhawatirkan juga berdampak pada menipisnya kearifan lokal masyarakat adat yang selama ini masih dihormati, seperti: 1) hidup selaras alam dengan menaati mekanisme ekosistem yang di dalamnya manusia menjadi bagian dari ekosistem yang harus dijaga keseimbangannya; 2) hak penguasaan dan /atau kepemilikan bersama komunitas atas suatu kawasan hutan adat yang bersifat eksklusif dan mengikat semua warga untuk menjaga dan mengamankannya drai kerusakan; 3) sistem pengetahuan dan struktur kelembagaan adat yang memberikan kemampuan bagi komunitas untuk memecahkan permasalahan yang berkaitan dengan pemanfaatan sumber daya alam; dan 4) mekanisme pemerataan distribusi hasil "panen" sumber daya alam milik komunal yang dapat meredam kecemburuan dan kesenjangan sosial di kalangan warga masyarakat adat (Bestari dan Abdon, 
2003). Dampak lain yang muncul adalah berubahnya pola-pola pengelolaan hutan, serta hilangnya hak ulayat dari masyarakat adat, di samping juga menipisnya peran lembaga-lembaga adat sebagai pengelola dan pengawas penerapan nilai-nilai adat yang dapat memberikan andil terhadap pergeseran nilai-nilai kearifan dalam pengelolaan hutan. Sementara dari aspek ekonomi, terjadi proses pemiskinan terhadap warga masyarakat adat, karena kurang terampilnya warga dalam pengelolaan hutan berpotensi melemahkan kemampuan masyarakat dalam menopang kebutuhan ekonomi.

Atas dasar itulah, walaupun status hutan adat dari kaca mata hukum formil tidak diakui, tetapi secara praksis tetap saja hutan adat merupakan bagian yang tidak terpisahkan dari kehidupan masyarakat adat. Berbedanya sistem nilai, konsep, dan strategi mengelola hutan antara masyarakat adat dengan pemerintah pasti berpotensi menimbulkan friksi, konflik, dan masalah.

\section{Penutup}

Pada penghujung tulisan ini dapat dikemukakan bahwa ketidakpastian pengelolaan masyarakat adat atas hutan diyakini sebagai salah satu penyebab deforestasi dan kemiskinan masyarakat adat di sekitar kawasan hutan. Selain itu, realitas kebijakan kehutanan yang sentralistik (Undang-Undang Kehutanan) telah menimbulkan tumpang tindihnya konsep hutan adat atas hutan negara di kawasan hutan, sementara aspek normatif yang kaku dari undang-undang tersebut telah menutup akses masyarakat adat terhadap hutan dan melemahkan peluang pengawasan berbasis kearifan tradisional dari masyarakat adat terhadap hutannya.

Bagi masyarakat adat, hutan adalah bagian dari sistem ulayat yang tidak bisa dipisahkan dari kehidupan mereka. Namun, faktanya pengelolaan hutan oleh masyarakat adat tidak diakomodasi dalam kebijakan kehutanan. Selama ini kebijakan kehutanan cenderung bersifat sentralistik, karena disandarkan pada pemerintah negara dan atau pemilik modal. Hal itu berpotensi memicu masalah dan tidak menguntungkan bagi masyarakat. Karena itu, pengaturan mengenai eksistensi hutan adat dan hak masyarakat adat untuk mengelola hutannya dengan prinsip hak ulayat adalah merupakan keniscayaan, karena solusi terhadap semua permasalahan kehutanan Indonesia hanya kearifan adat. Bagaimanapun, kearifan adat yang berbasis komunitas ini merupakan potensi sosial budaya yang sangat besar untuk direvitalisasi, diperkaya, dan diperkuat serta dikembangkan sebagai landasan baru untuk mengubah kebijakan pengelolaan sumber daya alam yang selama ini berpusat 
di tangan pemerintah dan terbukti menimbulkan pengrusakan hukum dan memarjinalkan ekonomi masyarakat adat di seluruh pelosok Indonesia. Meskipun demikian, untuk merealisasikan keberadaan masyarakat adat berikut hutannya harus dengan berpedoman pada peraturan yang berlaku.

Saat ini sudah saatnya cara pandang kebijakan pengelolaan sumber daya hutan hanya menjadi wewenang eksklusif dari instansi kehutanan ditinggalkan. Pengelolaan sumber daya hutan harus dipandang sebagai bagian dari pengelolaan sumber daya alam yang tunduk pada prinsip-prinsip pembangunan berkelanjutan dan berwawasan lingkungan serta berbasis kerakyatan, sehingga pengaturan mengenai pemanfataan sumber daya hutan adalah merupakan keniscayaan. Penentuan kawasan hutan diperlukan untuk membatasi luasnya wewenang pengelolaan pemanfaatan sumber daya hutan dan tidak dimaksudkan untuk memberikan wewenang mengatur penguasaan tanah di dalam kawasan hutan.

\section{Daftar Pustaka}

Abdon Nababan. 2002. Revitalisasi Hukum Adat untuk Menghentikan Penebangan Hutan secara Illegal di Indonesia. Kota:

Bestari Raden dan Abdon Nababan. 2003. Pengelolaan Hutan Berbasis Masyarakat Adat. Kota:

Nurul Firmansyah. 2006. "Dari Konflik Kehutanan Menuju Tata Kelola Hutan Berbasis Nagari." Makalah dalam Simposium Internasional Journal Antropologi Indonesia. Universitas Lambung Mangkurat. tanggal

Maria. S.W. Sumardjono. 2002. "Kebijakan Pertanahan antara Regulasi dan Implementasi. ” Jakarta. Kompas tanggal ...

Tempo, 17 Juni 2004. Hak Masyarakat Adat dan Masalah Kelestarian Lingkungan Hidup di Indonesia. Penulis

\section{Keterangan: Daftar Pustaka dan suber belum lengkap.}

Abdul Hakim. 2005. Pengantar Hukum Kehutanan Indonesia. Bandung: Citra Aditya Bakti

Badan Pembinaan Hukum Nasional. 1976. Seminar Hukum Adat dan Pembinaan Hukum Nasional. Bandung: Binacipta.

Hilman Hadikusuma. 2003. Pengantar Hukum Adat Indonesia. Bandung: Mandar.

Soerjono Soekanto dan Soleman B. Taneko. 1992. Hukum Adat, Suatu Pengantar Awal dan Prediksi Masa Mendatang. Bandung: Eresco. 
Biodata Penulis: 